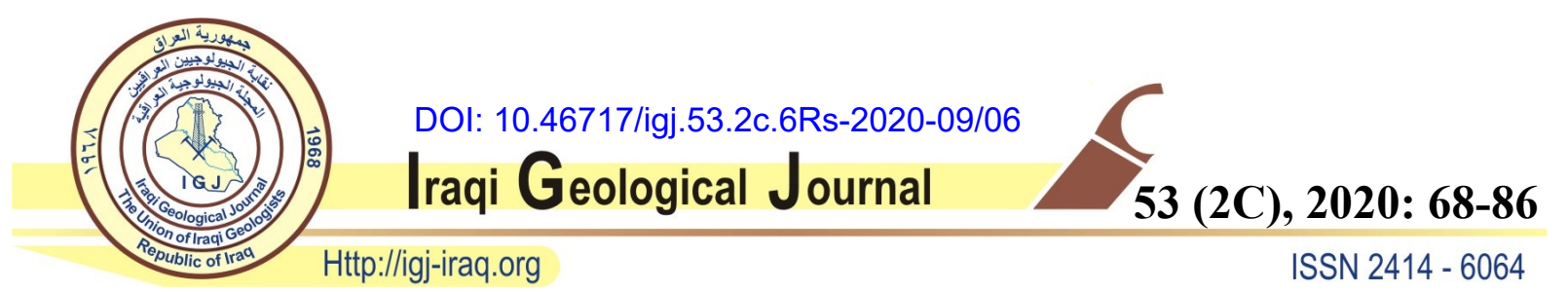

\title{
PALEOCLIMATIC INSIGHTS ON THE CENOMANIAN-TURONIAN OCEANIC ANOXIC EVENT (OAE2) FROM NORTHERN IRAQ BASED ON CALCAREOUS NANNOFOSSILS AND GEOCHEMICAL DATA
}

\author{
${ }^{1}$ Safwan Fathi Al-Lhaebi, ${ }^{1}$ Omar Ahmed Al-Badrani, ${ }^{1}$ Ali Ismail Al-Juboury ${ }^{*}$ and \\ ${ }^{2}$ Azam Mahanipour \\ ${ }^{1}$ Department of Geology, College of Science, University of Mosul, Mosul, Iraq \\ ${ }^{2}$ Department of Geology, Faculty of Science, Shahid Bahonar University of Kerman, Kerman, Iran \\ "E-mail: alialjubory@yahoo.com \\ Received: 27 May 2020; accepted: 11 June 2020
}

\begin{abstract}
Calcareous nannofossils, mineralogical and geochemical investigations are carried out on the Cenomanian-Turonian boundary of the Gulneri Formation in the Azmir, Dokan and Degala sections, northern Iraq. Regarding the calcareous nannofossil data CC11 and CC12 biozones were identified. A detailed investigation was carried out to identify calcareous nannofossils species. On the basis of their stratigraphic distribution, two biozones were proposed in this study; Quadrum gartneri Interval Biozone (CC11) part and Lucianrhabdus maleformis Interval Biozone (CC12) part. Correlation with other calcareous nannofossils biozones from regional schemes led to conclude that the age of the Gulneri Formation in the studied sections is the early Turonian. Mineralogical (X-ray diffraction XRD) and trace elements geochemistry (X-ray fluorescence XRF) data along with the dominance of calcareous nannofossil Watznauria that indicates warm and arid climatic condition prevailing in the Cenomanian-Turonian transition.
\end{abstract}

Keywords: Calcareous nannofossils; Trace elements; OAE2; Iraq

\section{INTRODUCTION}

Oceanic anoxic events (OAEs) are distinct features of the Cretaceous ocean with widespread marine anoxia events accompanied with accumulation of large amounts of organic carbon on the ocean floor in an oxygen-depletion conditions (Schlanger and Jenkyns, 1976 and Schlanger et al., 1987). OAE2 "Bonarelli event", which occurred approximately at the Cenomanian/Turonian boundary is the most widespread event in the mid-Cretaceous (Jenkyns, 2010). The Gulneri Formation represents one of the main Cretaceous shale formations deposited in euxinic and small relic basin in Iraq (Buday, 1980). Several sedimentological, biostratigraphical and geochemical studies have been subjected on the 
Gulneri Formation, both in outcrops at northern Iraq or in subsurface sections, but there are no more researches were undertaken to combine paleontological and geochemical data to reveal the OAE impact on the Gulneri Formation. Based on paleontological evidences, the Gulneri Formation that represent the Cenomanian-Turonian period in northern Iraq has been studied by many researchers that mentioned this formation may represent an oceanic anoxic event due to the presence of black layers rich in organic matter, dwarfing of some foraminiferal species, presence of low oxygen tolerant species and calcareous nannofossil distribution that may refer to anoxic conditions prevailing during deposition of these black layers (Buday, 1980; Abawi et al., 2006; Ameen and Gharib, 2014 and Al-Sagri, 2015). Other studies refer to a range of environmental conditions prevailing during deposition of the Gulneri rocks (dyoxic, suboxic, anoxic and euxinic) based on drowning due to differential subsidence (Haddad and Amin 2007) or common high organic matter content or oxygen deficient fossil species (Al-Dulaimy and Awadh, 2007). Mustafa and Tobia (2020) mentioned that the geochemical parameters have been used by to understand the paleo-oxygenation conditions of ancient sediments.

In the present work, calcareous nannofossil data along with mineralogical and geochemical analyses are conducted on the Gulneri Formation in three sections from northern Iraq (Dokan, Azmir and Degala sections) (Fig. 1) using calcareous nannofossil data along with clay mineralogical study (X-ray diffraction, XRD) and trace element geochemistry (Xray fluorescence, $\mathrm{XRF}$ ) aiming to interpret their implications on the climatic insights during this period.

\section{GEOLOGIC SETTING}

Gulneri Formation is firstly described by Jones (1957) in (Bellen et al., 1959) at its type section at Dokan Dam, Sulaimaniya Governorate, northeastern Iraq (Fig. 1) where it comprises of 1.2- 2 meters thick greyish black marl and marly limestone with fissile black shale and regarded as one of the Cenomanian-early Turonian sequence in Iraq.

The northeastern Iraq comprising a part of the Zagros Folded Zone, within the broader Taurus-Zagros Fold-and-Thrust Belt. This belt is a compressional one that is formed due to a closure of the Neo-Tethys oceanic basin as a result of convergence of the Arabian plate with continental Eurasia during the late Cretaceous and Cenozoic (Stocklin, 1968; Stampfli and Borel, 2002). 

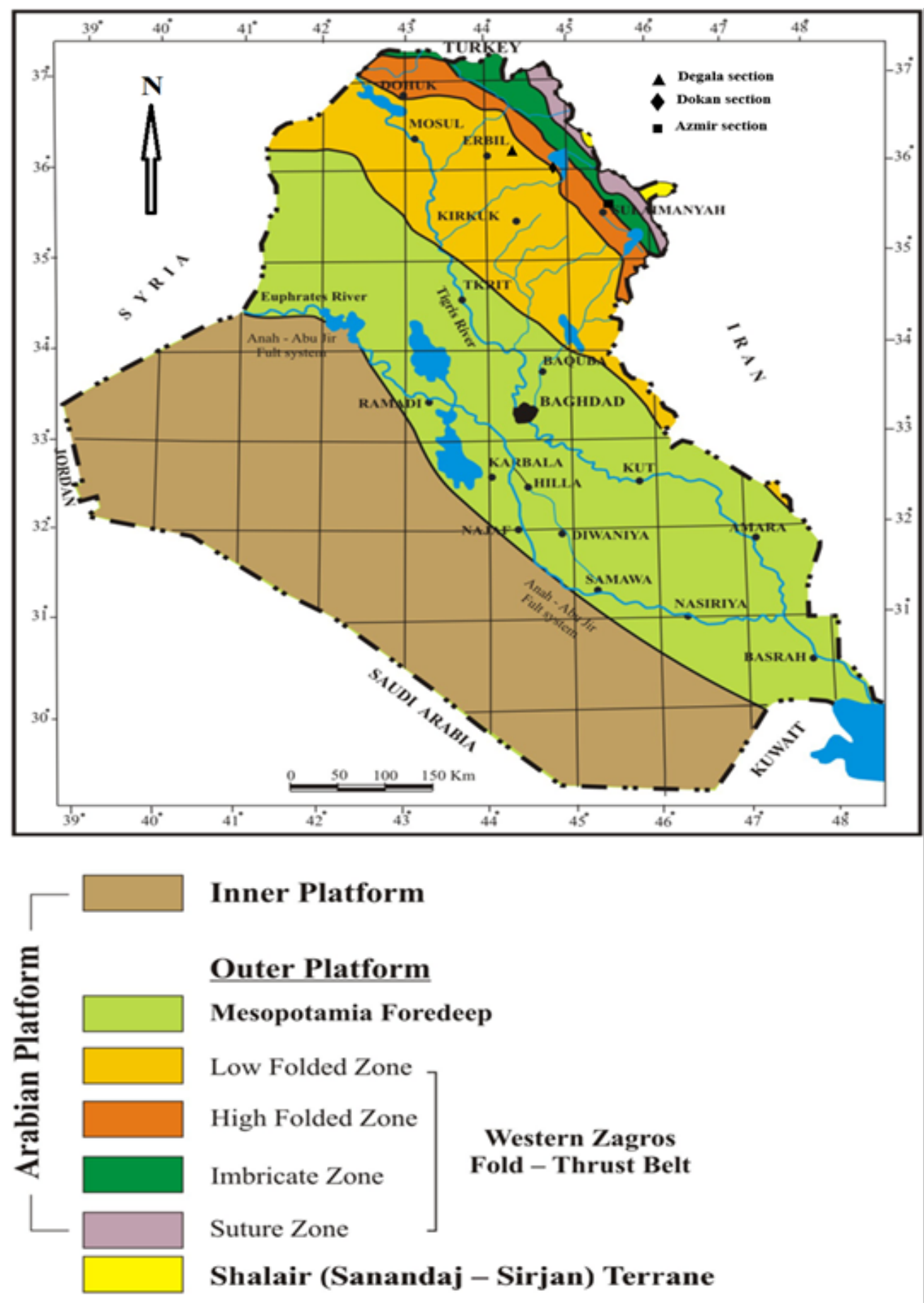

Fig. 1. Tectonic subdivisions of Iraq and location of the studied sections (after Fouad, 2015)

The study area locally is located in the Low and High Folded Zones of the Western Zagros Fold-Thrust belt of Iraq according to Jassim and Goff (2006) and the modified tectonic subdivisions of Iraq (Fig. 1). The three studied sections lie in the northeastern part of the Arabian Plate which form a part of the long and wide northern passive margin of Gondwana bordering the Paleo-Tethys Ocean (Sengör, 1990). 


\section{STUDY AREA}

The location of the studied sections is as follows:

\section{Azmir Section}

This section is located at the intersection of the road at the foot of the Salta Re Hill, which belongs to the Naugirdan Hills group, about $3.5 \mathrm{~km}$ northeast of the City of Sulaimaniya, southwest of the foot of Mount Azmer anticline at longitude $45^{\circ} 28$ '08.73' 'E and latitude $35^{\circ}$ 36 '13.84' 'N (Fig. 1).

\section{Dokan Section}

This section is located in the Kosrat Anticline at longitude $44^{\circ} 26^{\prime} 23^{\prime \prime}$ E and latitude $36^{\circ} 12^{\prime}$ $43 \mathrm{~N}$ " (Fig. 1).

\section{Degala Section}

This section is located about $36 \mathrm{~km}$ northeast of the Erbil city between Degla and Aliawa village, in the southern limp of the Bina-Bawi anticline at longitude 44 26 '23"E and latitude $36^{\circ} 12^{\prime} 43^{\prime} \mathrm{N}$ (Fig. 1).

\section{MATERIALS AND METHODS}

A total of 15 samples were selected for the calcareous nannofossil study using the simple smear slide technique using the method of Armstrong and Brasier (2005). The prepared slides were studied under a transmitted-light microscope (Olympus BH2). Thirty-two samples are analyzed using X-Ray Diffraction (XRD), (Table 1). A randomly oriented X-ray powder diffractogram was obtained using Spellman DF3 diffractometer. Quantitative determination was made using the SIROQUANT V3 program developed by the CSIRO (Commonwealth Scientific and Industrial Research Organization), Australia. Analyses were carried out in the laboratories of Wollongong University, Australia. Element analysis of 35 samples were carried out at ACME Analytical Laboratories using ICP-AES for the determination of trace elements. Samples measured on glass pellets which were produced in platinum-gold crucible adding $1 / 5$ ratio of sample and lithium tetraborate $\left(\mathrm{Li}_{2} \mathrm{~B}_{4} \mathrm{O}_{7}\right)$ at $1150{ }^{\circ} \mathrm{C}$.

\section{RESULTS}

\section{Calcareous Nannofossil Biostratigraphy}

Regarding the calcareous nannofossil biostratigraphy, the age of the Gulneri Formation in Azmir and Degala sections must be considered late Cenomanian as Helenea chiastia which is a marker for the top of UC5 (UC5c) with the age of late Cenomanian is observed. In Dokan section E. eximius is recorded Eiffellithus eximius is recorded which is a marker for the base of UC8a (middle Turonian), but we cannot find L. septenarius and L. maleformis. Regarding 
these data the age of the Gulneri Formation in Azmir and Degala sections is late Cenomanian while in Dokan section is middle Turonian.

\section{Quadrum gartneri interval biozone (CC11)}

Definition: Interval from first occurrence of Quadrum gartneri to first occurrence of Lucianorhabdus maleformis.

Thickness: (350) cm. in Azmir section, (145) cm.in Dokan and (420) cm. in Degala section. Boundaries and discussion: The lower boundary of this biozone is not exposed in the studied area which is marked by first occurrence of Quadrum gartneri, the upper boundary is marked by the first occurrence of Lucianorhabdus maleformis, which did not record recently but the first occurrence of Eiffellithus eximius is recorded. The zone is correlated with Quadrum gartneri biozone by Sissingh (1977) and with lower part of Eiffellithus eximius biozone by Verbeek (1977) and with Quadrum gartneri biozone (14D) by Mortimer (1987), all aged as early Turonian (Figs. 2 and 3) (Plate 1)

\section{Lucianrhabdus maleformis interval biozone (CC12)}

Definition: Interval from first occurrence of Lucianorhabdus maleformis to first occurrence of Marthastrites furcatus.

Thickness: (300) cm. in Azmir section

Boundaries and discussion: The lower boundary is marked by first occurrence of which did not record recently, but the first occurrence of Eiffellithus eximius is recorded, whereas, the upper boundary is of this biozone not exposed in the studied area which is marked by the first occurrence of Marthastrites furcatus. This zone is correlated with Lucianrhabdus maleformis biozone by Sissingh (1977) and with upper part of Eiffellithus eximius biozone by Verbeek (1977) and with Eiffellithus eximius biozone (14C) by Mortimer (1987), all aged as early Turonian (Figs. 2 and 3) (Plate 1).

\section{Mineralogy}

XRD study revealed the dominance of illite, mixed layers (illite/smectite, I/S), chlorite and kaolinite (Table 1 and Fig. 4). In Azmir section, illite ranges in content from 1.5-6\% (average 4.4\%), I/S 1-5.1\% (average 3.5\%), chlorite $0-0.9 \%$ (average $0.6 \%$ ) and kaolinite $0.3-1 \%$ (average 0.6\%). In Dokan section; illite ranges in content from 1-6.8\% (average 2.7\%), I/S 1.9-7.1\% (average 4.4\%), chlorite $0-1.7 \%$ (average 0.3 ) and kaolinite 0-0.6 (average 0.3\%). Whereas, in Degala section, illite ranges from $0.4-1.8 \%$ (average $1.17 \%$ ), and $\mathrm{I} / \mathrm{S}$ 0.5-1.5 (average 0.9\%). 


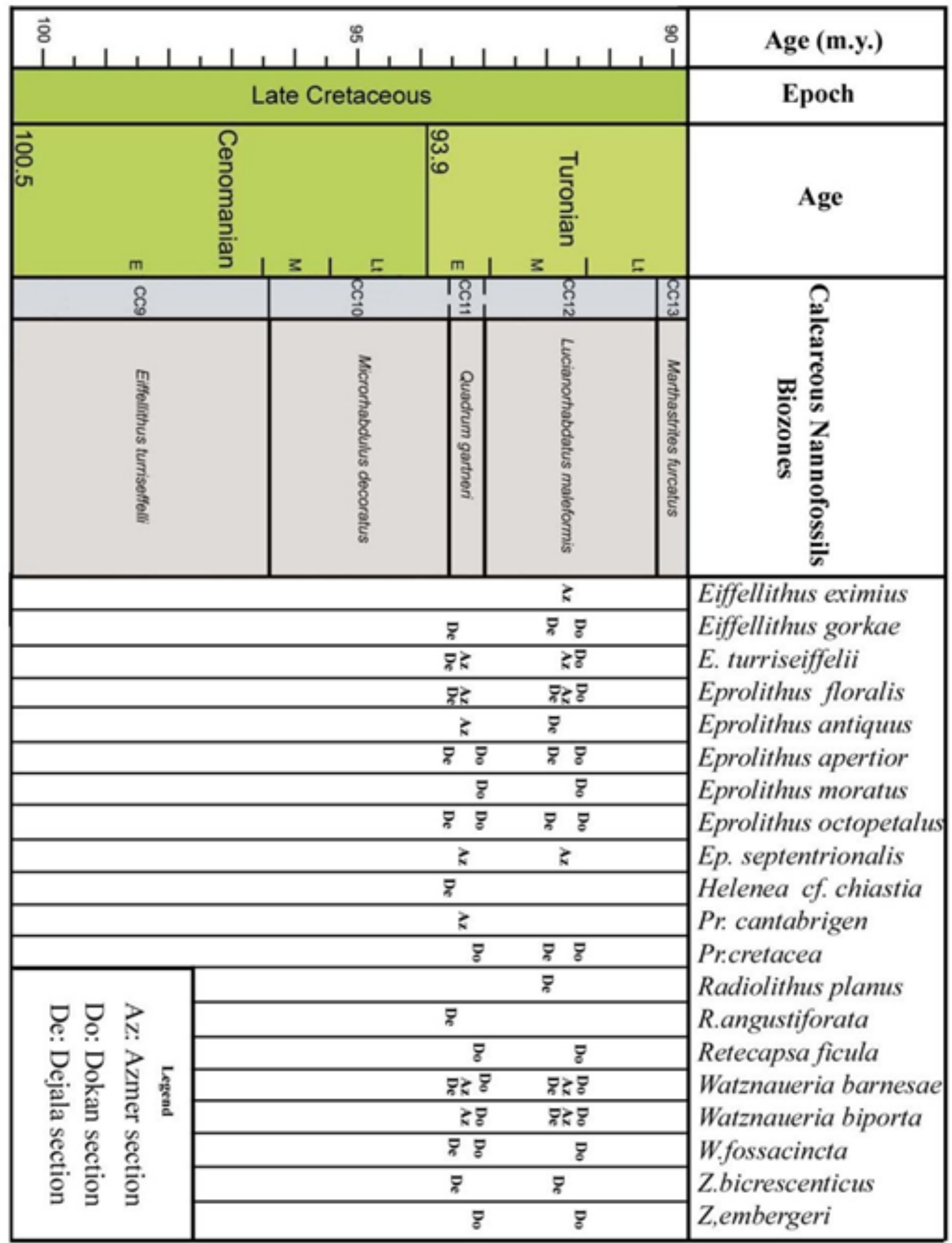

Fig. 2. Calcareous nannofossils biozones from Azmir, Dokan and Degala sections 


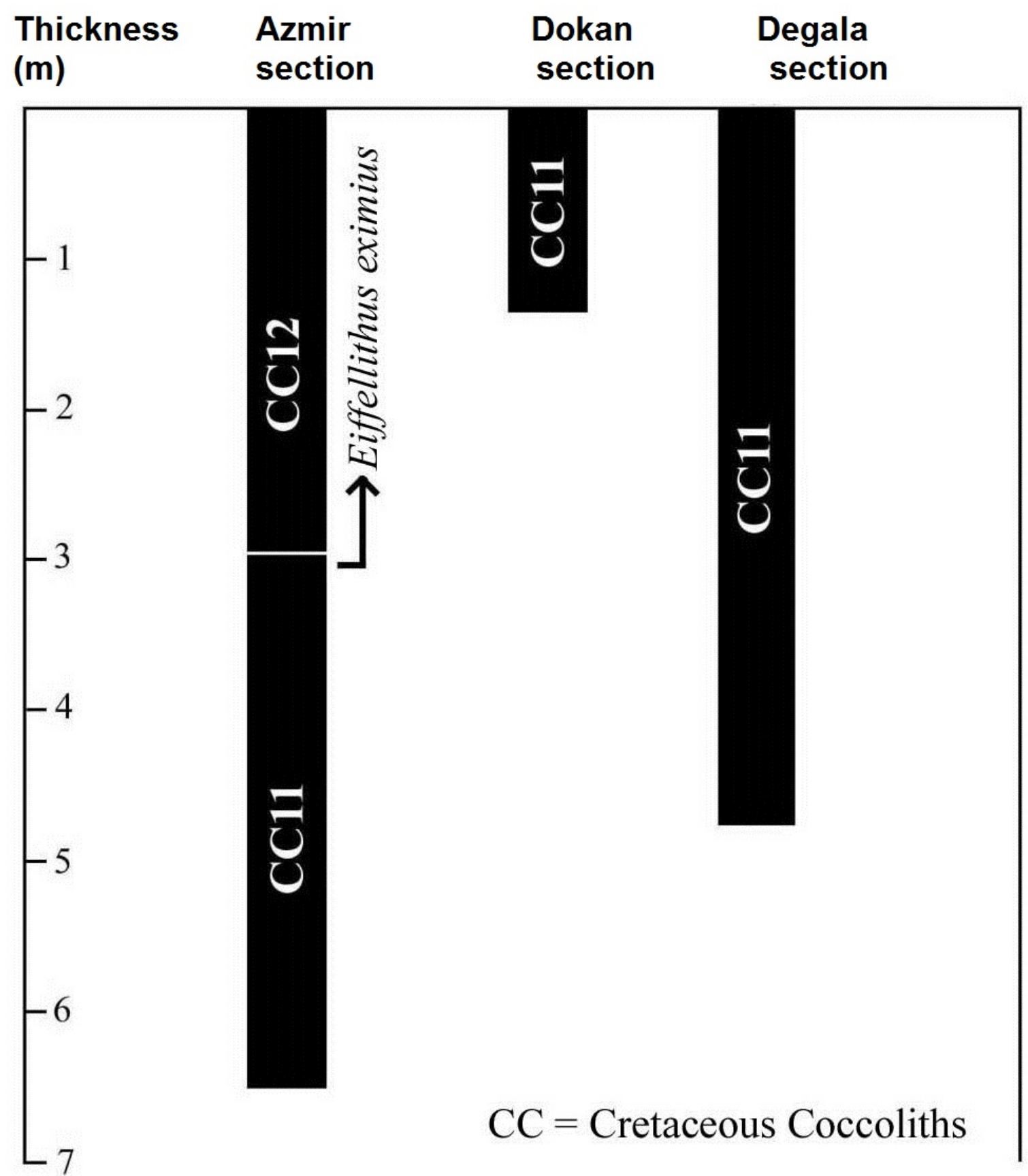

Fig. 3. Age determination for the Gulneri Formation in Azmir, Dokan and Degala sections 

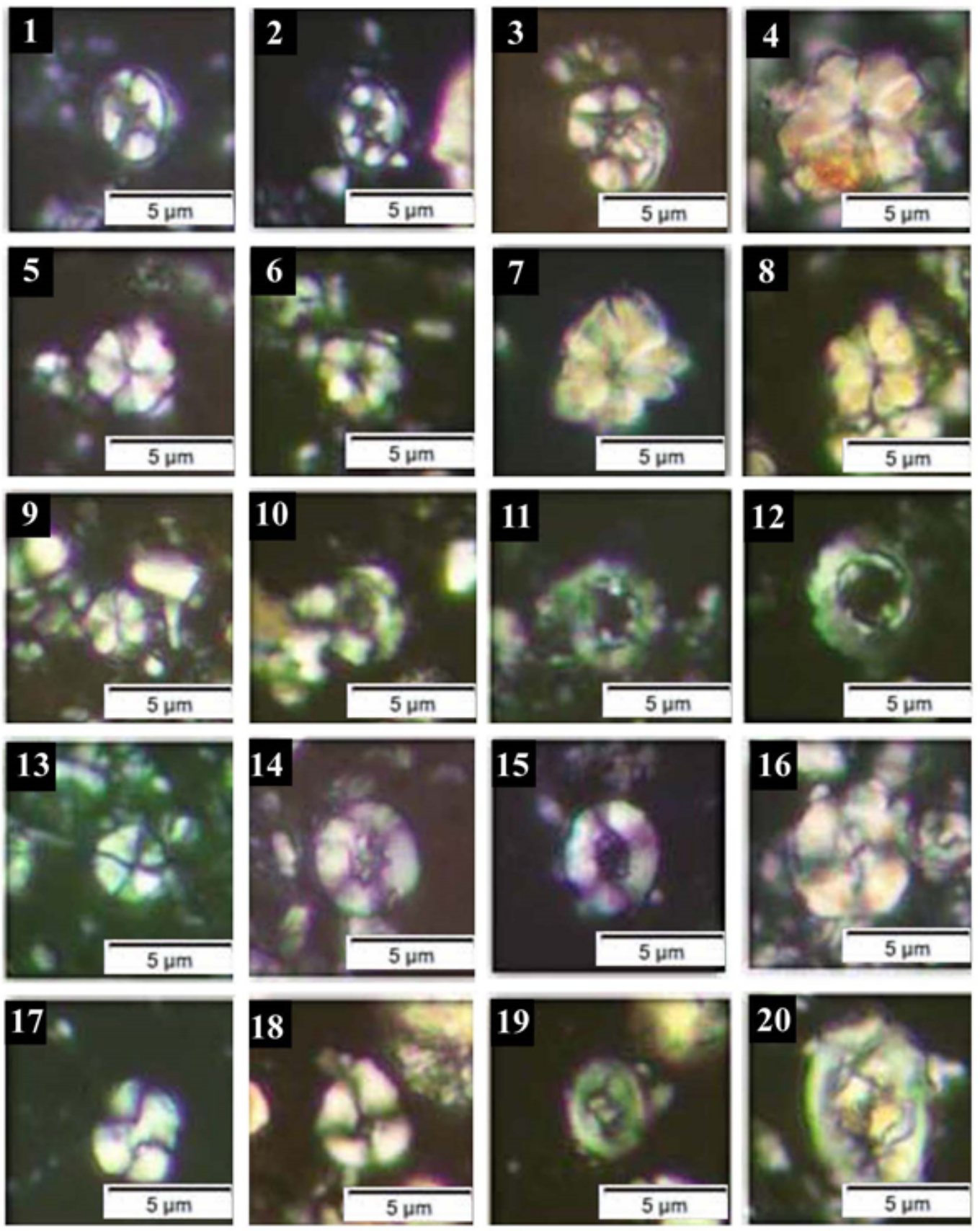

Explanations Plate 1. Cross-polarized light photos of significant calcareous nannofossil taxa from studied sections. (1) Eiffellithus eximius; (2) Eiffellithus gorkae; (3) Eiffellithus turriseiffelii; (4) Eprolithus antiquus; (5) Eprolithus apertior; (6) Eprolithus floralis; (7) Eprolithus moratus; (8) Eprolithus octopetalus; (9) Eprolithus septentrionalis; (10) Helenea cf. chiastia; (11) Prediscosphaera columnata; (12) Prediscosphaera cretacea; (13) Radiolithus planus; (14) Retecapsa angustiforata; (15) Retecapsa ficula; (16) Watznaueria barnesae; (17) Watznaueria biporta; (18) Watznaueria fossacincta; (19) Zeugrhabdotus bicrescenticus; (20) Zeugrhabdotus embergeri. 
Table 1. Clay minerals distribution in the studied sections

\begin{tabular}{|c|c|c|c|c|c|}
\hline Section & Sample number & Kaolinite\% & Chlorite\% & Illite\% & $\begin{array}{c}\text { Mixed layer illite } \\
\text { I/S \% }\end{array}$ \\
\hline \multirow{9}{*}{ Azmir } & $26 \mathrm{Gz}$ & 0.4 & 0.4 & 4.8 & 3.5 \\
\hline & $26 \mathrm{Gz}$ & 0.4 & 0.4 & 4.8 & 3.5 \\
\hline & $23 \mathrm{Gz}$ & 0.9 & 0.5 & 4.9 & 5.1 \\
\hline & $22 \mathrm{Gz}$ & & 0 & 6 & 1 \\
\hline & $15 \mathrm{Gz}$ & 0.4 & 0.9 & 5.1 & 3.4 \\
\hline & $13 \mathrm{Gz}$ & 1.3 & 0.9 & 5.2 & 3.9 \\
\hline & $11 \mathrm{Gz}$ & 0.4 & 0.4 & 3 & 3.5 \\
\hline & $6 \mathrm{Gz}$ & 0.3 & 0.9 & 4.5 & 4.1 \\
\hline & $2 \mathrm{Gz}$ & & & 1.5 & 3.4 \\
\hline \multirow{21}{*}{ Dokan } & 25Do & 0 & 0.3 & 4 & 2.9 \\
\hline & 23Do & 0 & 1.7 & 6.8 & 3.7 \\
\hline & 22Do & & & & 6.7 \\
\hline & 21Do & 0.2 & 1 & 3.9 & 2.8 \\
\hline & 19Do & 0.6 & 0.4 & 4.1 & 1.9 \\
\hline & 18Do & & & 1.6 & 2.8 \\
\hline & 17Do & 0.6 & 0.3 & 3.5 & 2 \\
\hline & 16Do & & 00 & 1.9 & 3.6 \\
\hline & 15Do & & 0 & 2.4 & 4.1 \\
\hline & 14Do & & 0 & 1.9 & 6.1 \\
\hline & 13Do & & 0 & 1 & 6.9 \\
\hline & 12Do & & 0 & 1.3 & 5.5 \\
\hline & 11Do & & 0 & 1.5 & 3.9 \\
\hline & 10Do & 0.2 & 1 & 4 & 2.6 \\
\hline & 9Do & & 0 & 2 & 7.1 \\
\hline & 8Do & & 0 & 2.3 & 7.0 \\
\hline & 6Do & & 0 & 1.3 & 5.2 \\
\hline & $5 \mathrm{DO}$ & & 0 & 1.5 & 5.5 \\
\hline & 4Do & & 0 & 1.6 & 5.1 \\
\hline & 3Do & 0.4 & 1.2 & 4.4 & 4.3 \\
\hline & 2Do & 0.4 & 0.5 & 3.6 & 2.6 \\
\hline \multirow{3}{*}{ Degala } & $21 \mathrm{Dj}$ & & & 1.3 & 1.5 \\
\hline & 17Dj & & & 0.4 & 0.6 \\
\hline & $14 \mathrm{Dj}$ & & & 1.8 & 0.5 \\
\hline
\end{tabular}



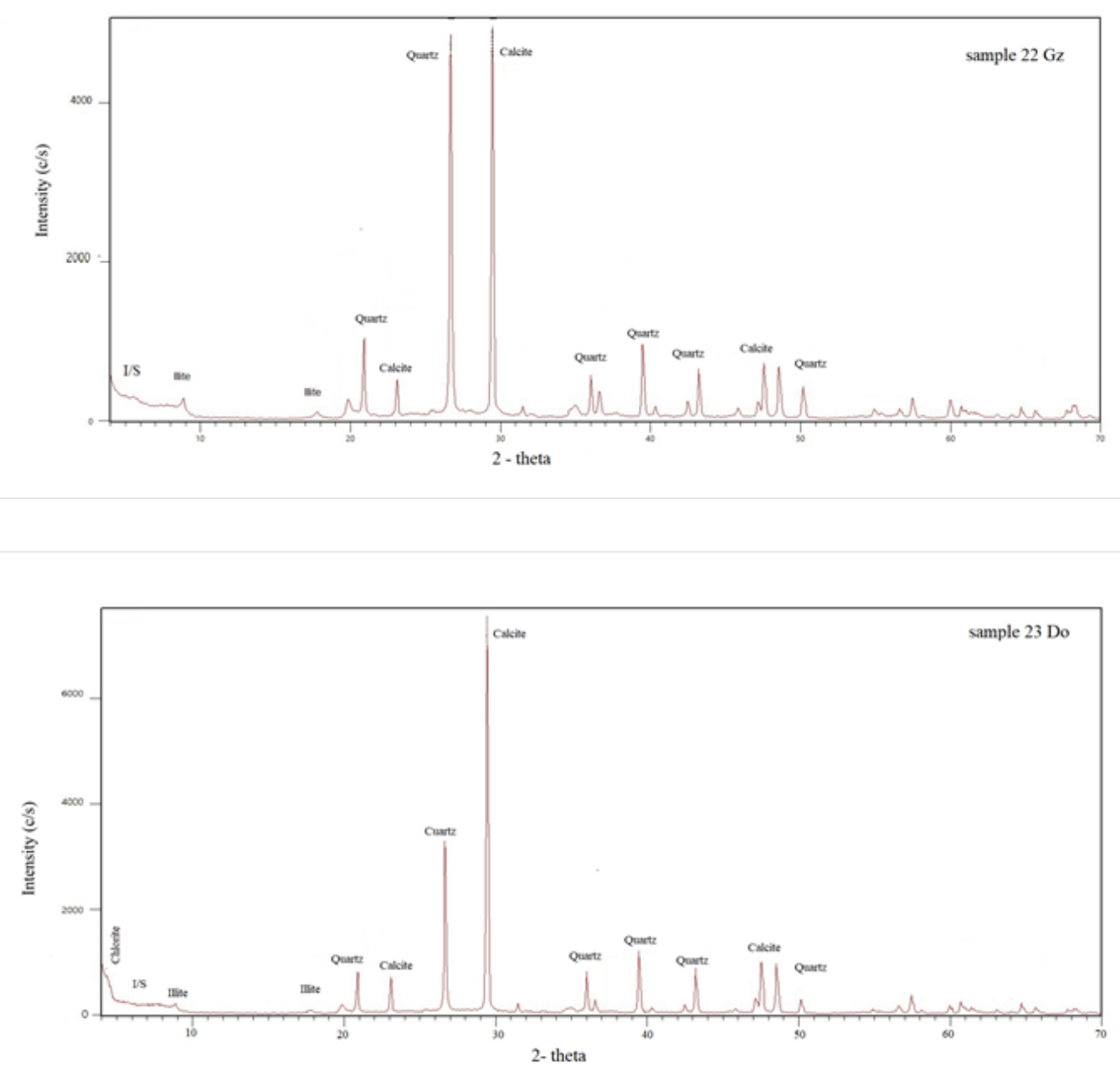

Fig. 4. X-ray diffractograms for two selected samples showing the common clay and non-clay minerals

\section{Geochemistry}

Several elemental ratios are used to determine paleoclimatic conditions of the studied rocks of the Gulneri Formation (Table 2 and Figs. 5, 7). The ratio of $\mathrm{Ga} / \mathrm{Rb}$ in the Gulneri Formation in Azmir section ranges between $0.11-0.14$ with an average of 0.1 , in Degala section, it ranges between 0.04-0.09 with an average of 0.07 while in Dokan section it ranges between 0.05-0.16 with an average of 0.12 . In warm, humid climatic conditions salinity reduced, while hot and arid climatic conditions lead to rapid and abrupt elevation in salinity (Roy and Roser, 2013).

The $\mathrm{Ga} / \mathrm{Rb}$ ratio can be used to obtain information about the ancient climate (Roy and Roser, 2013; Yandoka et al., 2015). In general, the Rb is associated with the illite which indicates the cold and arid climate. Therefore, the deposit that has a low value for the ratio of $\mathrm{Ga} / \mathrm{Rb}$ indicates the cold and dry climate. On the other hand, the Ga has a significant 
enrichment in kaolinite, which indicates the warm climate as $\mathrm{Ga} / \mathrm{Rb}$ ratio. Cross plot between $\mathrm{Ga} / \mathrm{Rb}$ vs $\mathrm{Sr} / \mathrm{Cu}$ is displayed in Fig. 8. Based on this plot, the studied samples of the Gulneri Formation were deposited in a hot arid environment Roy and Roser, 2013; Yandoka et al., 2015). $\mathrm{The} \mathrm{Rb} / \mathrm{Sr}$ and the $\mathrm{Sr} / \mathrm{Cu}$ ratios commonly are used as paleoclimatic indications (Sinha et al., 2006; $\mathrm{Xu}$ et al., 2010). Under warmer climatic conditions, the $\mathrm{Rb} / \mathrm{Sr}$ ratio decreases while the $\mathrm{Sr} / \mathrm{Cu}$ ratio values increase. The $\mathrm{Rb} / \mathrm{Sr}$ ratio in Azmir section ranges between 0.023 and 0.195 with an average of 0.064 . In Degala section it ranges between 0.022 to 0.050 with an average of 0.035 , whereas, the range in Dokan section is between 0.019 to 0.06 with an average of 0.039 .

The $\mathrm{Sr} / \mathrm{Ba}$ ratio is useful for estimating the paleosalinity of calcareous rocks. Ratio greater than 1 indicates marine environment, while ratio between $0.6-1.0$ indicates transitional from marine to continental, while those less than 0.6 refers to continental environments (Zheng and Liu, 1999). In general, the high $\mathrm{Sr} / \mathrm{Ba}$ ratio reflects the high salinity or arid climate, while the low ratio indicates low salinity or humid climate (Wang et al., 2017). The $\mathrm{Sr} / \mathrm{Ba}$ ratio in Azmir section is between 0.083-10.05 at an average of 4.09, in Degala section the ratio is $5.495-12.71$ with an average of 8.3 while in Dokan section it ranges between 0.63-8.28 at an average of 3.06 (Table 2). These ratios indicate an arid climate and high salinity conditions. The $\mathrm{Sr} / \mathrm{Cu}$ ratio, which ranges from (1.3-5.0), indicates a warm humid climate, while the ratio greater than 5.0 indicates a hot and arid climate (Yandoka et al., 2015; Song et al., 2016). The values of the $\mathrm{Sr} / \mathrm{Cu}$ ratio in Azmir section is 14.7- 97.9 with an average of 28.14, in Degala section is 28-59 with an average of 36.096, in Dokan, it ranges between 13.9-28.4 with an average of 19.85. These values are all above 5, which indicates that the climate is arid and hot.

\section{Climatic Factor "C"}

In the present work, the value of ' $c$ ' as an important climate factor (Ding et al., 2018) is used and the formula for "c" is as follows:

$$
\mathrm{C}=\Sigma(\mathrm{Fe}+\mathrm{Mn}+\mathrm{Cr}+\mathrm{Ni}+\mathrm{V}+\mathrm{Co}) / \Sigma(\mathrm{Ca}+\mathrm{Mg}+\mathrm{Sr}+\mathrm{Ba}+\mathrm{K}+\mathrm{Na})
$$

Values between 0-0.2 indicate an arid climate and those between 0.2-0.4 indicate a semiarid climate and the value between $0.4-0.6$ refer to a semiarid-semi-humid climate semi-arid-semihumid and values between $0.6-0.8$ indicate a semi humid climate and the value of $0.8-1.0$ indicate a humid climate. The value of "c" in Azmir section is 0.041, and in the Dokan section is at a rate of 0.017 and in Degala section is at the range of 0.001 . These values show that the studied Gulneri Formation was deposited in an arid climate condition. 
Table 2. Geochemical ratios of selected trace elements and C-value of selected samples of the Gulneri Formation in Azmir, Degala and Dokan sections

\begin{tabular}{|c|c|c|c|c|c|c|c|c|c|c|}
\hline Section & $\begin{array}{c}\text { Sample } \\
\text { No. }\end{array}$ & $\begin{array}{c}\mathrm{Ba} \\
(\mathrm{ppm})\end{array}$ & $\begin{array}{c}\mathbf{R b} \\
(\mathbf{p p m})\end{array}$ & $\begin{array}{c}\text { Ga } \\
(\mathbf{p p m})\end{array}$ & $\underset{(p p m)}{\mathrm{Sr}}$ & $\begin{array}{c}\mathrm{Cu} \\
(\mathrm{ppm})\end{array}$ & $\mathrm{Sr} / \mathrm{Cu}$ & $\mathbf{S r} / \mathbf{B a}$ & $\mathbf{G a} / \mathbf{R b}$ & $\mathbf{R b} / \mathbf{S r}$ \\
\hline \multirow{11}{*}{ Azmir } & $37 \mathrm{Gz}$ & 304 & 48.0 & & 667 & 45 & 14.7 & 2.2 & 0.000 & 0.072 \\
\hline & $35 \mathrm{Gz}$ & 411 & 27.9 & & 831 & 28 & 29.9 & 2.0 & 0.000 & 0.034 \\
\hline & $30 \mathrm{Gz}$ & 8525 & 45.0 & & 705 & 42 & 16.7 & 0.1 & 0.000 & 0.064 \\
\hline & $26 \mathrm{Gz}$ & 86 & 33.3 & 4.923 & 865 & 40 & 21.4 & 10.0 & 0.148 & 0.039 \\
\hline & $23 \mathrm{Gz}$ & 448 & 45.3 & 6.245 & 547 & 52 & 10.6 & 1.2 & 0.138 & 0.083 \\
\hline & $19 \mathrm{Gz}$ & 145 & 18.3 & & 812 & 25 & 32.1 & 5.6 & 0.000 & 0.023 \\
\hline & $13 \mathrm{Gz}$ & 154 & 40.0 & 5.89 & 551 & 64 & 8.6 & 3.6 & 0.147 & 0.073 \\
\hline & $9 \mathrm{Gz}$ & 138 & 19.2 & & 764 & 16 & 48.1 & 5.5 & 0.000 & 0.025 \\
\hline & $7 \mathrm{Gz}$ & 135 & 21.6 & & 710 & 18 & 40.1 & 5.3 & 0.000 & 0.030 \\
\hline & $6 \mathrm{Gz}$ & 178 & 43.1 & 4.76 & 634 & 67 & 9.4 & 3.6 & 0.110 & 0.068 \\
\hline & $3 \mathrm{Gz}$ & & & & 369 & 45 & 8.1 & 1.7 & 0.000 & 0.195 \\
\hline Section & $\begin{array}{c}\text { Sample } \\
\text { No. }\end{array}$ & $\begin{array}{c}\mathbf{B a} \\
(\mathbf{p p m})\end{array}$ & $\begin{array}{c}\mathbf{R b} \\
(\mathbf{p p m})\end{array}$ & $\begin{array}{c}\text { Ga } \\
(\mathrm{ppm})\end{array}$ & $\begin{array}{c}\mathrm{Sr} \\
(\mathrm{ppm})\end{array}$ & $\begin{array}{c}\mathrm{Cu} \\
(\mathrm{ppm})\end{array}$ & $\mathrm{Sr} / \mathrm{Cu}$ & $\mathrm{Sr} / \mathrm{Ba}$ & $\mathbf{G a} / \mathbf{R b}$ & $\mathbf{R b} / \mathbf{S r}$ \\
\hline \multirow{10}{*}{ Degala } & 27Dj & 23.0 & 6.8 & & 292.3 & 9.5 & 30.8 & 12.7 & & 0.023 \\
\hline & $25 \mathrm{Dj}$ & 28.0 & 7.3 & & 331.6 & 9.8 & 33.8 & 11.8 & & 0.022 \\
\hline & 22Dj & 48.0 & 15.5 & 1.1000 & 325.1 & 10.3 & 31.6 & 6.8 & 0.0710 & 0.048 \\
\hline & 19Dj & 44.0 & 13.1 & 1.3000 & 367.1 & 10.9 & 33.7 & 8.3 & 0.0992 & 0.036 \\
\hline & 16Dj & 45.0 & 11.7 & $<0.5$ & 407.4 & 11.2 & 36.4 & 9.1 & & 0.029 \\
\hline & $13 \mathrm{Dj}$ & 46.0 & 10.9 & $<0.5$ & 428.7 & 7.2 & 59.5 & 9.3 & & 0.025 \\
\hline & 11Dj & 56.0 & 19.0 & 0.8000 & 393.3 & 11.8 & 33.3 & 7.0 & 0.0421 & 0.048 \\
\hline & 9Dj & 83.0 & 18.4 & 0.7000 & 486.0 & 15.9 & 30.6 & 5.9 & 0.0380 & 0.038 \\
\hline & $6 \mathrm{Dj}$ & 72.0 & 13.8 & $<0.5$ & 439.5 & 10.3 & 42.7 & 6.1 & & 0.031 \\
\hline & $2 \mathrm{Dj}$ & 74.0 & 20.5 & 1.9000 & 406.6 & 14.2 & 28.6 & 5.5 & 0.0927 & 0.050 \\
\hline Section & $\begin{array}{c}\text { Sample } \\
\text { No. }\end{array}$ & Ba ppm & Rbppm & $\begin{array}{c}\mathbf{G a} \\
(\mathrm{ppm})\end{array}$ & om & pm & $\mathrm{r} / \mathrm{Cu}$ & $\mathbf{B a}$ & /Rb & Sr \\
\hline \multirow{18}{*}{ Dokan } & 21 Do & 231.074 & 26.635 & 2.671 & 496.378 & 25.887 & 19.175 & 2.148 & 0.100 & 0.054 \\
\hline & 20 Do & 280.252 & 25.169 & 3.423 & 554.701 & 31.261 & 17.744 & 1.979 & 0.136 & 0.045 \\
\hline & 19 Do & 466.891 & 19.823 & 1.837 & 575.019 & 20.248 & 28.398 & 1.232 & 0.093 & 0.034 \\
\hline & 18 Do & 217.281 & \begin{tabular}{|l|}
15.660 \\
\end{tabular} & 1.655 & 509.596 & 22.641 & 22.508 & 2.345 & 0.106 & 0.031 \\
\hline & 17 Do & 890.622 & 10.181 & 0.531 & 562.808 & 25.721 & 21.882 & 0.632 & 0.052 & 0.018 \\
\hline & 16 Do & 261.307 & \begin{tabular}{|l|}
17.160 \\
\end{tabular} & 2.570 & 601.237 & 25.822 & 23.284 & 2.301 & 0.150 & 0.029 \\
\hline & 15 Do & 140.044 & \begin{tabular}{|l|}
20.531 \\
\end{tabular} & 2.408 & 555.620 & 23.573 & 23.570 & 3.967 & 0.117 & 0.037 \\
\hline & 14 Do & 121.332 & \begin{tabular}{|l|}
21.436 \\
\end{tabular} & 2.060 & 519.478 & \begin{tabular}{|l|}
31.297 \\
\end{tabular} & 16.598 & 4.281 & 0.096 & 0.041 \\
\hline & 13 Do & 237.795 & 19.732 & 1.941 & 546.683 & 24.096 & 22.688 & 2.299 & 0.098 & 0.036 \\
\hline & 12 Do & 66.630 & 19.035 & 2.378 & 551.960 & 26.493 & 20.834 & 8.284 & 0.125 & 0.034 \\
\hline & 11 Do & 213.805 & 24.821 & 1.802 & 497.246 & 24.933 & 19.943 & 2.326 & 0.073 & 0.050 \\
\hline & 10 Do & 182.076 & \begin{tabular}{|l|}
31.108 \\
\end{tabular} & 3.435 & 527.936 & 35.183 & 15.005 & 2.900 & 0.110 & 0.059 \\
\hline & 9 Do & 196.382 & 26.016 & 2.937 & 602.721 & 35.636 & 16.913 & 3.069 & 0.113 & 0.043 \\
\hline & 8 Do & 122.411 & \begin{tabular}{|l|}
24.655 \\
\end{tabular} & 3.933 & 519.533 & 28.166 & 18.446 & 4.244 & 0.160 & 0.047 \\
\hline & 6 Do & 206.286 & \begin{tabular}{|l|}
17.443 \\
\end{tabular} & 1.846 & 595.106 & 29.952 & 19.868 & 2.885 & 0.106 & 0.029 \\
\hline & 5 Do & 129.804 & 18.594 & 2.878 & 492.954 & 35.440 & 13.910 & 3.798 & 0.155 & 0.038 \\
\hline & 4 Do & 175.529 & \begin{tabular}{|l|}
19.621 \\
\end{tabular} & 1.497 & 583.610 & 30.813 & 18.940 & 3.325 & 0.076 & 0.034 \\
\hline & 3 Do & 183.652 & 29.465 & 2.456 & 567.371 & 32.123 & 17.662 & 3.089 & 0.083 & 0.052 \\
\hline
\end{tabular}




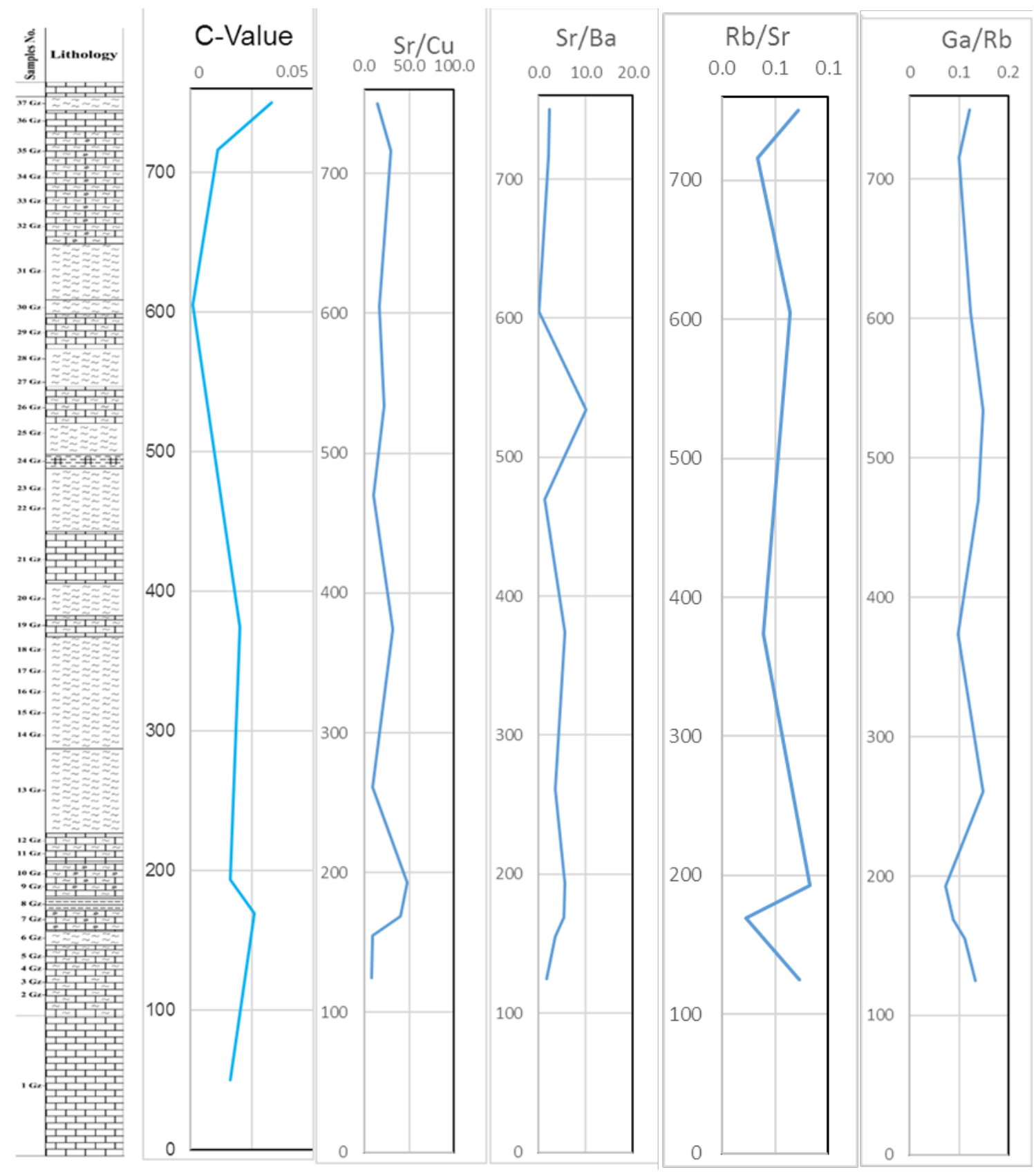

Fig. 5. Chart showing stratigraphic variation in trace elements ratios in the Azmir section 


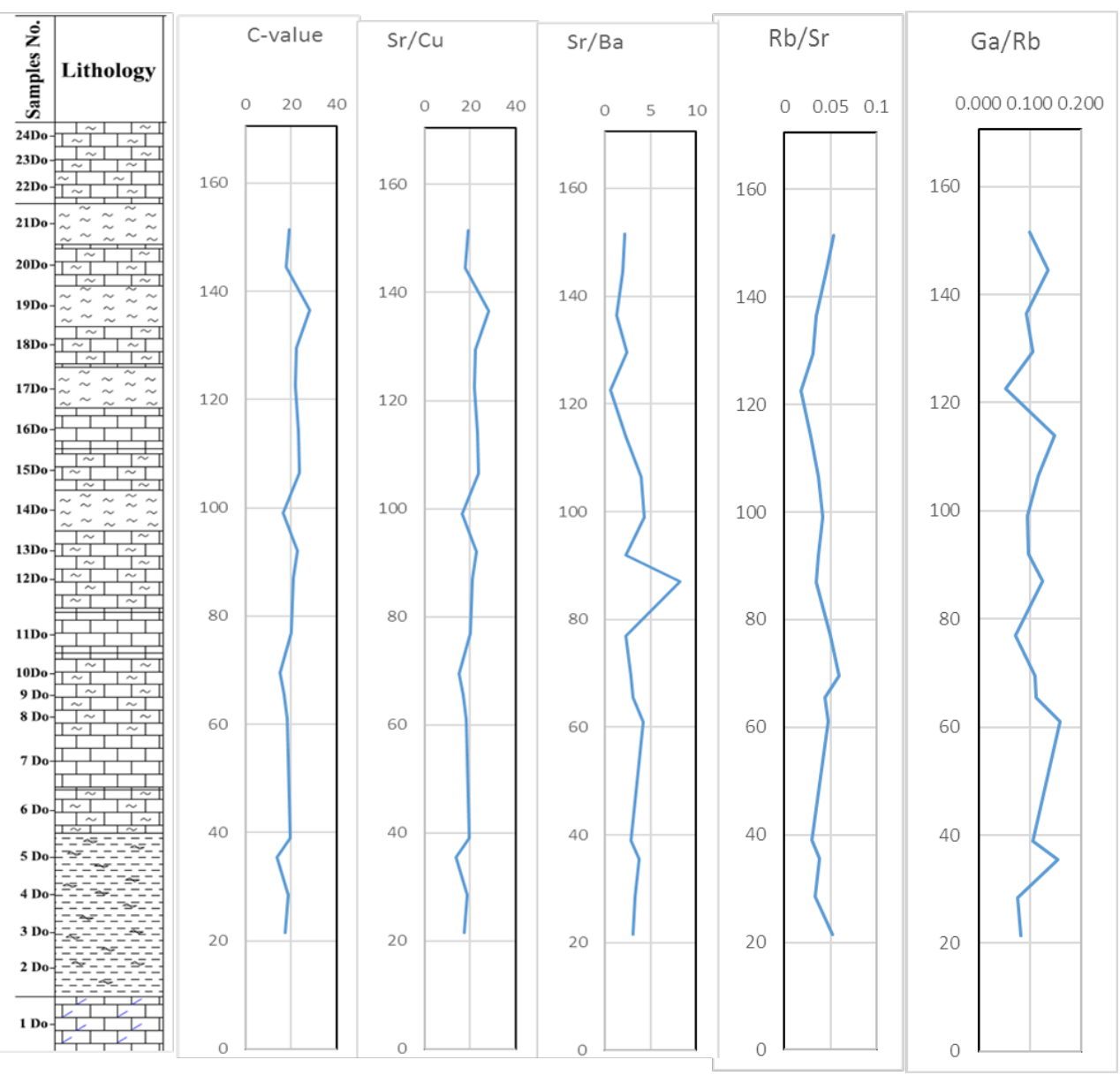

Fig. 6. Chart showing stratigraphic variation in trace elements ratios in the Dokan section

\section{DISCUSSION}

\section{Biostratigraphy and Paleoclimate Traced by Calcareous Nannofossils}

Calcareous nannofossil data indicate that the studied intervals are early Turonian in age. This period was marked by major environmental changes at regional to global scale including the early Turonian Oceanic Anoxic Event (OAE2). Several multidisciplinary researches were focused on OAEs which relate the event to the excess of $\mathrm{CO}_{2}$, intense volcanism and altered climate and oceanic chemistry (Corbett and Watkins, 2013 and Aguado et al., 2016). Calcareous nannoplanktons are extremely sensitive to changes in surface waters parameters such as; temperature, nutrient content and interacts with the carbon cycle through biological processes and production of calcareous oozes. Therefore, they are used as a tool to understand the marine ecosystem dynamics of the past. Calcareous nannofossil from the Tethys Ocean mentioned to climatic fluctuations and changes in ocean fertility during the early Turonian. Over this time interval, the Tethys Ocean was characterized by phases of black shale deposition controlled by orbital forcing (Jarvis et al., 2011). Calcaroeus nannofossil 
Watznauria is commonly used as a paleoclimatic warm water indicator (Giraud et al., 2006). The abundance of Watznauria in the studied sections among other calcareous nannofossils may indicate warm conditions.

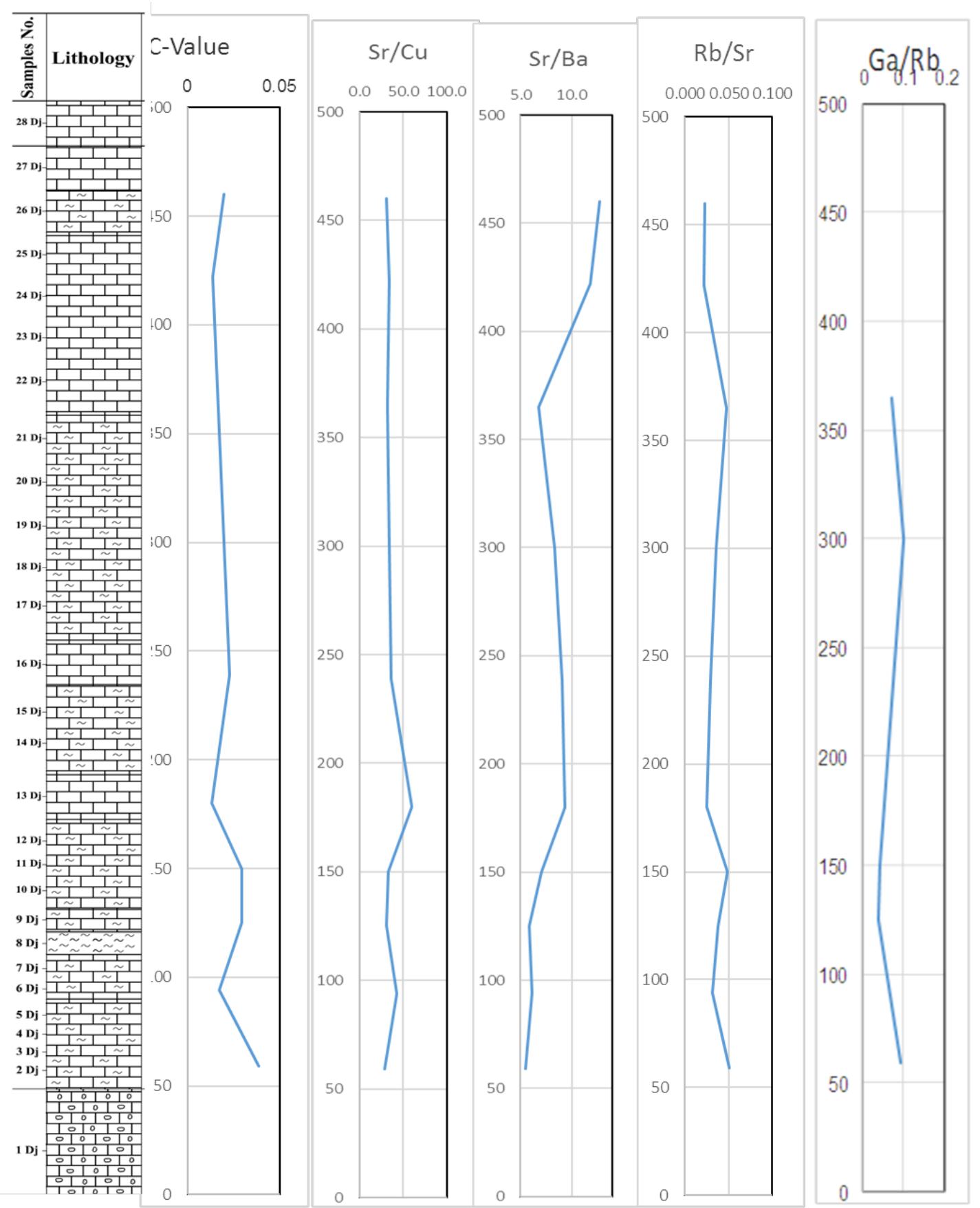

Fig. 7. Chart of stratigraphic variation in trace elements ratios in the Degala section 


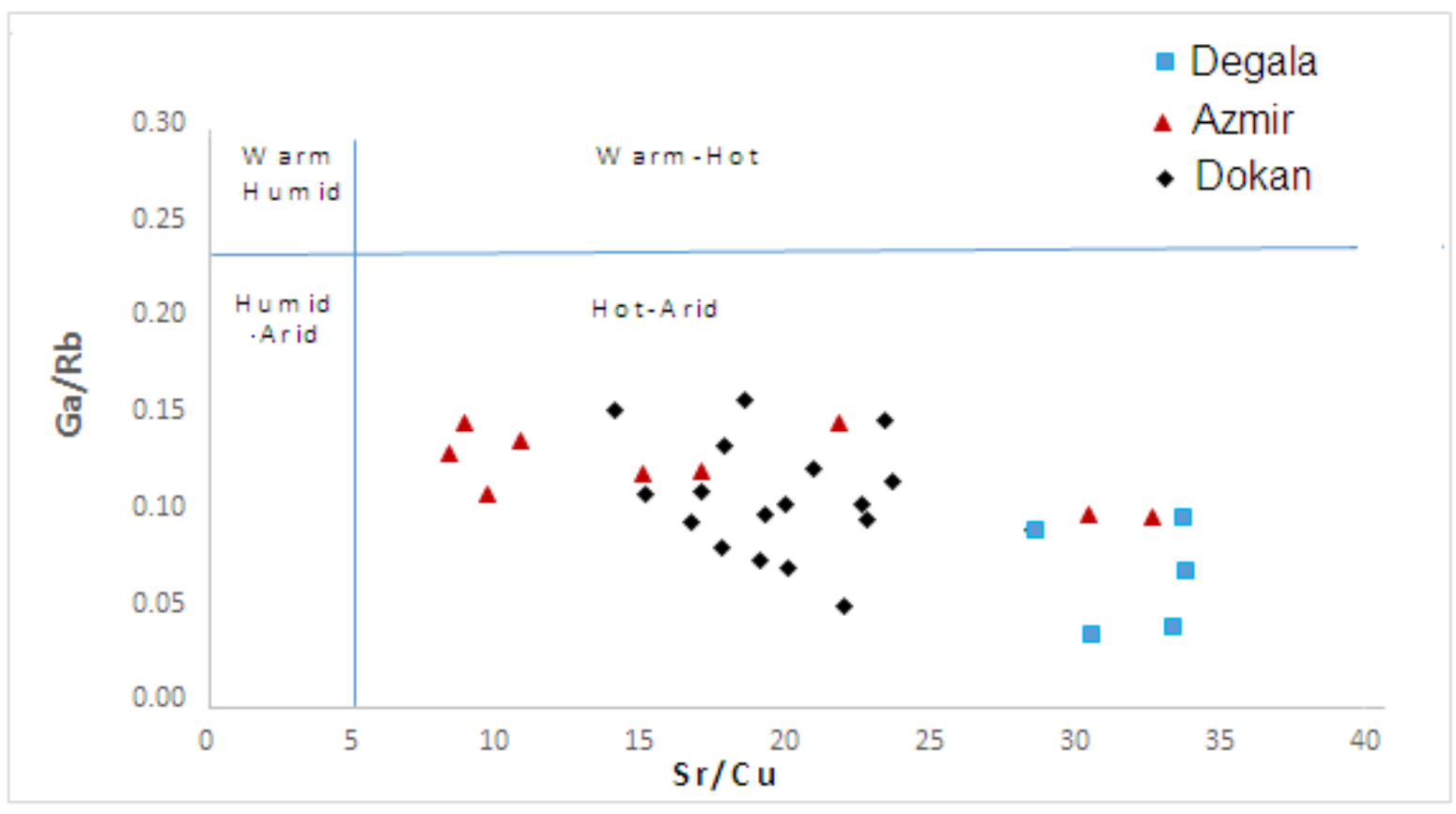

Fig. 8. Cross plot between $\mathrm{Ga} / \mathrm{Rb}$ vs $\mathrm{Sr} / \mathrm{Cu}$ of the Gulneri Formation

\section{Climatic Evidence of the Clay Minerals}

The clay minerals (kaolinite and smectite) are considered a proxy for chemical weathering (hydrolysis) which are prevalent in the most humid climate, while illite is considered as physical weathering mineral index that prevails in arid climatic conditions (Kunhardt 2016). Whereas, high ratio of mixed clay (illite/smectite) is produced from dry and arid climatic conditions (Chamley, 1989 and Dera et al. 2009). The abundance of illite and chlorite and the low content of kaolinite indicate high salinity and may be related to transgression while abundance of kaolinite and low content of illite and chlorite indicates low salinity (Cao et al., 2015). Low amounts of kaolinite accompanied with relatively abundance of illite and illite/smectite mixed layers clay minerals in the Gulneri Formation may refer to the semi-arid or arid climatic of the source region.

\section{Geochemical Constraints}

The $\mathrm{Ga} / \mathrm{Rb}$ ratio can be used to obtain information about the paleoclimate (Roy and Roser, 2013 and Yandoka et al., 2015). In general, the $\mathrm{Rb}$ is associated with the illite which indicates the cold and arid climate. Therefore, the deposit that has a low value for the ratio of $\mathrm{Ga} / \mathrm{Rb}$ indicates the cold and dry climate. On the other hand, the Ga has a significant enrichment in kaolinite, which indicates the warm climate. Other used ratios, $\mathrm{Rb} / \mathrm{Sr}, \mathrm{Sr} / \mathrm{Ba}$ and $\mathrm{Sr} / \mathrm{Cu}$ indicate that the studied rocks were deposited in hot, arid climates. The relative content and distribution of some trace elements in fine-sized rocks can be used to derive their climatic conditions during deposition (Ding et al., 2018). Elements of manganese, iron, vanadium, 
chromium and cobalt were relatively rich in humid climatic conditions. On the contrary, the elements calcium, magnesium, centrum, barium, potassium and sodium are rich in upwelling areas or areas with ascending alkalinity due to evaporation under arid conditions that facilitate the precipitation of salt minerals (Ding et al., 2018).

Based on the above climate factor "C" (Ding et al., 2018):

$$
\mathrm{C}=\Sigma(\mathrm{Fe}+\mathrm{Mn}+\mathrm{Cr}+\mathrm{Ni}+\mathrm{V}+\mathrm{Co}) / \Sigma(\mathrm{Ca}+\mathrm{Mg}+\mathrm{Sr}+\mathrm{Ba}+\mathrm{K}+\mathrm{Na})
$$

The studied rocks are deduced also to be precipitated in arid climate.

\section{CONCLUSIONS}

Calcareous nannofossils were documented from the Cretaceous Gulneri Formation at three sections from northern Iraq supported with mineralogical (X-ray diffraction XRD) and trace elements geochemistry (X-ray fluorescence XRF) data aiming to determine the paleoclimatic insights on the Cenomanian-Turonian Oceanic Anoxic Event (OAE2). Biostratigraphic study revealed that the age of the Gulneri Formation in the studied sections is early Turonian. The dominance of calcareous nannofossil Watznauria with relative abundance of the clay minerals illite and illite/smectite mixed layers in the Gulneri Formation indicate warm water in semiarid or arid climatic conditions of the source region. Geochemical data from $\mathrm{Ga} / \mathrm{Rb}, \mathrm{Rb} / \mathrm{Sr}$, $\mathrm{Sr} / \mathrm{Ba}$ and $\mathrm{Sr} / \mathrm{Cu}$ ratios along with the climate factor " $\mathrm{C}$ " also indicate warm an arid climatic condition prevailing in the Cenomanian-Turonian transition.

\section{ACKNOWLEDGMENTS}

The authors are very grateful to the College of Science, University of Mosul for their provided facilities, which helped to improve the quality of this work. The authors are very grateful to the Editor in Chief Prof. Dr. Salih M. Awadh, the Secretary of Journal Mr. Samir R. Hijab and the Technical Editor Dr. Heba S. Al-Mimar for their great efforts and valuable comments.

\section{REFERENCES}

Abawi, T. S., Hammoudi, R. A., and Al-Khafaf, A. O., 2006. Stratigraphy of the Gulneri Formation (Upper Cretaceous) in the type Section, Dokan, Northeastern Iraq. Iraqi Journal of Earth Sciences, 6(2): 33-42.

Aguado, R., Reolid, M., and Molina, E., 2016. Response of calcareous nannoplankton to the late Cretaceous Oceanic Anoxic Event 2 at Oued Bahloul (central Tunisia). Palaeogeography, Palaeoclimatology, Palaeoecology. 459: 289-305.

Al-Dulaimy, A. S., and Awadh, S. M., 2007. Geochemical, palaeontological Study of Gulneri Formation (upper Cretaceous) NE-Iraq. Anbar Journal of Science, 1(1): 1-11.

Armstrong, H. and Brasier, M. 2005. Microfossils, Blackwell Publishing.

Al-Sagri, K. E. A., 2015. Linking the timing of deposition and organic matter richness of the Gulneri Formation of Northern Iraq to the global oceanic anoxic event 2. Iraqi Journal of Science, 56(3A): 2007-2023.

Ameen, F. A., and Gharib, H., 2014. Biostratigraphy of the Tethyan Cretaceous successions from northwestern Zagros fold-thrust belt, Kurdistan region, NE Iraq. Arabian Journal of Geosciences. 7: 2689-2710. 
Bellen, R. C., Van Dunnington, H.V., Wetzel, R., and Morton, D. M., 1959. Lexique Stratigraphic International, V.III: Asie, Fasc. 10 a, Iraq.

Buday, T., 1980. The Regional Geology of Iraq. Stratigraphy and Palaeogeography, Dar Al-Kutub Publishing.

Cao, H., Guo, W., Shan, X., Ma, L., and Sun, P., 2015. Paleolimnological environments and organic accumulation of the Nenjiang Formation in the Southeastern Songliao Basin. China. Oil Shale, 32:5-24.

Chamley, H., 1989, Clay Sedimentology: Springer-Verlag, London, New York.

Corbett, M. J., and Watkins, D. K., 2013. Calcareous nannofossil paleoecology of the mid-Cretaceous Western Interior Seaway and evidence of oligotrophic surface waters during OAE2. Palaeogeography, Palaeoclimatology, Palaeoecology. 392: 510-523.

Dera, G., Pellenard, P., Neige, P., Deconinck, J.-F., Pucéat, E., and Dommergues, J.L., 2009. Distribution of clay minerals in Early Jurassic Peritethyan seas: Palaeoclimatic significance inferred from multiproxy comparisons Palaeogeography, Palaeoclimatology, Palaeoecology. 271: 39-51.

Ding, J., Zhang, J., Tang, X., Huo, Z., Han, S., Lang, Y., and Liu, T., 2018. Elemental geochemical evidence for depositional conditions and organic matter enrichment of black rock series strata in an inter-platform basin: The Lower Carboniferous Datang formation, Southwest China. Minerals, 8(11): 509-538.

Fouad, S. F. A., 2015. Tectonic map of Iraq, scale 1: 1000 000, 3rd edition, Iraqi Bulletin of Geology and Mining. 11: 1-7.

Giraud, F., Pittet, B., Mattioli, E., and Audouin, V., 2006. Paleoenvironmental controls on the morphology and abundance of the coccolith Watznaueria britannica (Late Jurassic, southern Germany). Marine Micropaleontology. 60 (3): 205-225.

Haddad, S. N. S., and Amin, M. A., 2007. Mid-Turonian-early Campanian sequence stratigraphy of northeast Iraq. GeoArabia, 12(2): 135-176.

Jarvis, I., Lignum, J. S., Gröcke, D. R., Jenkyns, H. C., and Pearce, M. A., 2011. Black shale deposition, atmospheric $\mathrm{CO} 2$ drawdown, and cooling during the Cenomanian-Turonian Oceanic Anoxic Event. Paleoceanography. 26, PA3201, doi: 10.1029/2010PA002081.

Jassim, S. Z., and Goff, J. 2006. Geology of Iraq. Dolin, Prague and Maravian Museum, Brno.

Jenkyns, H. C., 2010. Geochemistry of oceanic anoxic events. Geochemistry, Geophysics, Geosystems. 11: 1-30.

Kunhardt, C. G., 2016. Cyclostratigraphy and Sedimentation of the Cenomanian- Turonian Tuscaloosa Marine Shale, Ph. D Thesis, University of Mississippi.

Mortimer, C.P., 1987. Upper cretaceous calcareous nannofossil biostrtigraphy of the southern Norwegian and Danish North Sea area. Anhandlungen der Geologischen Bundesanstalt, 39: 143-175

Mustafa, R. K., and Tobia, F. H., 2020. Geochemical application in unraveling paleoweathering, provenance and environmental setting of the shale from Chia Gara Formation, Kurdistan Region, Iraq, Iraqi Geological Journal, 53 (1A): 90-116.

Roy, D. K., and Roser, B. P., 2013. Climatic control on the composition of Carboniferous-Permian Gondwana sediments, Khalaspir basin, Bangladesh. Gondwana Res. 23 (3): 1163-1171.

Sengör, A. M. C., 1990. A new model for the Late Palaeozoic-Mesozoic tectonic evolution of Iran and implications for Oman, in Robertson, Seale, and Ries, eds., The Geology and Tectonics of the Oman Region, Geological Society of London Special Publication. 49: 797-831.

Sinha, R., Smykatz-Kloss, W., Stüben, D., Harrison, S. P., Berner, Z., and Kramar, U., 2006. Late Quaternary palaeoclimatic reconstruction from the lacustrine sediments of the Sambhar playa core, Thar Desert margin, India. Palaeogeography, Palaeoclimatology, Palaeoecology, 233: 252-270.

Sissingh, W., 1977. Biostratigraphy of Cretaceous calcareous nannoplankton. In: Bolli, H. M., Saunders, J. B., and Perch-Nielsen, K. (eds.), 1985, Plankton stratigraphy. Cambridge University Press, 329-426.

Schlanger, S. O., and Jenkyns, H. C., 1976. Cretaceous anoxic events: causes and consequences. Geol. Mijnb., 55: $179-184$.

Schlanger, S. O., Arthur, M. A., Jenkyns, H. C., and Scholle, P. A., 1987. The Cenomanian-Turonian Oceanic anoxic event, I. Stratigraphy and distribution of organic carbon-rich beds and the marine $\delta 13 \mathrm{C}$ excursion. Geological Society, London, 26: 371-399

Song, Y., Liu, Z., Meng, Q., Xu, J., Sun, P., Cheng, L., and Zheng, G., 2016. Multiple controlling factors of the enrichment of organic matter in the upper cretaceous oil shale sequences of the Songliao basin, NE China: implications from geochemical analyses. Oil Shale, 33: 142-166. 
Stampfli, G. M., and Borel, G., D., 2002. A plate tectonic model for the Paleozoic and Mesozoic constrained by dynamic plate boundaries and restored synthetic oceanic isochrones. Earth and Planetary Science Letters, 196: 17-33.

Stocklin, J. 1968. Structural history and tectonics of Iran: a review. American Association of Petroleum Geologists Bulletin, 52: 1229-1258.

Verbeek, J. W., 1977. Calcareous nannoplankton biostratigraphy of middle and upper Cretaceous deposits in Tunisia, southern Spain and France. Utrecht Micropaleontology Bulletin, 16: 1-157.

Wang, Z., Fu, X., Feng, X., Song, C., Wang, D., Chen, W., and Zeng, S., 2017. Geochemical features of the black shales from the Wuyu Basin, southern Tibet: implications for palaeoenvironment and palaeoclimate. Geological Journal. 52 (2): 282297.

$\mathrm{Xu}, \mathrm{H}$., Liu, B., and Wu, F., 2010. Spatial and temporal variations of Rb/Sr ratios of the bulk surface sediments in Lake Qinghai. Geochemical Transactions, 11: 1-8.

Yandoka, B. M. S., Abdullah, W. H., Abubakar, M. B., Hakimi, M. H., and Adegoke, A. K., 2015. Geochemical characterization of early Cretaceous lacustrine sediments of Bima Formation, Yola Sub-basin, northern Benue trough, NE Nigeria: organic matter input, preservation, paleoenvironment and palaeoclimatic conditions. Marine and Petroleum Geology, 61: 82-94.

Zheng, R., and Liu, H., 1999. Study on palaeosalinity of Chang-6 oil reservoir set in Ordos Basin. Oil Gas Geology. 20: 20-25. 